\title{
Towards Improving ESP Teaching/Learning in Vietnam's Higher Education Institutions: Integrating Project-Based Learning into ESP Courses
}

\author{
Nguyen Van Khanh
}

\begin{abstract}
As Vietnam is integrating into the global economy, the learning of English is no longer for its own justification but for using the language in a variety of contexts. Given this situation, ESP courses have been incorporated into foreign language curricula of higher education institutions in Vietnam. The pedagogical trend towards more communicative approaches in language teaching, however, has challenged the current traditional approach employed in ESP teaching. This paper examines salient issues concerning ESP teaching/learning practice in Vietnam and proposes the integration of PBL into current ESP courses an alternative to overcome the above problems.
\end{abstract}

Index Terms - ESP, problems, project-based learning.

\section{INTRODUCTION}

Similar to the case of Russian language, which was once the ruling foreign language in Vietnam, English was introduced to the country first to meet the increasing demand of receiving knowledge from the Western world, especially in the field of science and technology. Since Vietnam's reform in 1986 and the collapse of the Soviet Union, English took over the position of Russian and became a de facto foreign language in Vietnam. The last two decades have witnessed a surge in English language teaching/ learning in the country. As Vietnam is integrating into the world economy, the citizens are required to not only have a sound English knowledge for daily communication but also for interpreting specialist content [1]. This demand calls for a revision of English for Specific Purposes (ESP) practice, which focused on building learners' repertoire of technical terms and enhancing their skills of reading and translation. In the shift toward integrating communicative aspects of English language into ESP courses in Vietnam, approaches such as Content-based instruction, Task-based learning, and Problem-based learning have been introduced. Promoting learning through project works is not a novel idea as early $20^{\text {th }}$ century educators employed this approach in their classrooms [2], and PBL's recent application in second language education have attracted the attention of both teachers and learners. Considering the context of Vietnam, Project-Based Learning should be integrated into current ESP courses as it helps solve problems facing ESP practitioners and learners. This paper examines salient issues concerning ESP teaching/learning practice in Vietnam and proposes the integration of PBL into

Manuscript received October 4, 2015; revised December 18, 2015.

Nguyen Van Khanh is with the Monash University, Australia (e-mail: khanhnv135@gmail.com). current ESP courses an alternative to overcome the above problems.

\section{ESP, CBI AND PBL}

English for Specific Purposes has emerged and became an important trend in English Language Teaching (ELT) since 1960s [3], [4]. Hutchinson and Waters define ESP as "an approach to language learning, which is based on learner need" [3]. Following this basic definition, other scholars specify this term more intensively. For example, Wright, as in [4], writes "ESP is, basically, language learning which has its focus on all aspects of language pertaining to a particular field of human activity, while taking into account the time constraints imposed by learners." whilst Dudley-Evans , as in [4] defines ESP in terms of its "absolute" and "variable" characteristics. However, all agree on the nature of ESP as a learner-centered approach which motivates learners through addressing their specific needs in learning the language [3], [4].

Upon implementing ESP, Content-Based Instruction (CBI) has been proved to be an effective approach. $\mathrm{CBI}$ is defined as "an approach to second language teaching in which teaching is organised around the content or information that students will acquire, rather than around a linguistic or other type of syllabus" (Richards \& Rodger as in [1]). In their empirical researches, Kavaliauskiene [5] and Nguyen [1] prove that CBI helps improve students' motivation and academic achievement in ESP course as this learner-centered approach allows learners to practice language skills and acquire subject knowledge simultaneously. Kavaliauskiene [5] further argues that CBI can be implemented through Project work or Project based-learning (PBL) as this approach nourishes collaborative learning, encourages students' involvement, interaction and responsibility.

That PBL is learner-centered and comprises the integration of all language skills and content learning makes this approach applicable for ESP teaching. The concept of Project-based learning was introduced into second language education for more than two decades as an effort to provide L2 learners with opportunities to produce comprehensible output or, in other words, to practice four language skills in authentic contexts [2]. As found in general education and L2 education literature, the term Project-based learning is used interchangeably with a variety of terms such as project work, project method, project approach and project-oriented approach [2]; however, for the purpose of this paper, the term Project-Based learning will be employed. Whether it is 
defined as broadly as "an approach to instruction that teaches curriculum concepts through a project" [6] or in such a specific fashion as "a systematic teaching method that engages students in learning essential knowledge and life enhancing skills through an extended, student-influenced inquiry process structured around complex, authentic questions and carefully designed products and tasks." [7], the prominent feature of this approach is to engage students in real world tasks in which students learn content knowledge and practice language skill simultaneously [2]. In general, project implementation is composed of four stages: Speculation, Designing the project activities, Conducting the project activities and Evaluation (Kriwas as in [8]).

\section{ESP PRACTICE IN VIETNAM}

English has seized the dominating status of Russian and French language to become the most popular foreign language in Vietnam since 1990s. As Vietnam is integrating into the global economy, the learning of English is no longer for its own justification but for using the language in a variety of contexts. Given this situation, ESP course has been incorporated into foreign language curricula of higher education institutions in Vietnam. It is compulsory for students to complete ESP modules before graduating. This arm of ELT has also attracted attention of both local education researchers and practitioners in recent years. However, the practice of these (ESP) courses has posed quite a few challenges to learners and practitioners, which will be examined hereafter.

\section{A. Teacher-Related Problems}

Firstly, there is a confusion of ESP teachers, either from the onset or during the course, about the objectives of ESP: teaching specialist knowledge or language skills. This confusion is attributable to an approach focusing on grammar and terminology that is currently popular in teaching ESP not only in Vietnam but also in other cultures [1], [9]-[11] Specifically, from methodological perspective, this disorientation incited an emphasis on limited linguistic aspects such as memorizing specialist terms and doing exercises on basic grammar rules while neglecting communicative aspects of the language. This approach has given rise to issues related to students' motivation and learning methods which will be discussed latter in this paper. An imbalance in language learning and subject learning is also observed as a consequence of this confusion [12]. Tabatabaei blames this problem for limited time allocated for ESP course and enormous amount of content (both language and subject) to be taught [13]. Also, inadequate attention paid to ESP teacher education which leads to English as a Foreign Language (EFL) teachers' struggling and having to learn about ESP pedagogy through their practice is another explanation for this confusion [14].

Excessive workload is another issue facing Vietnamese ESP teachers. This problem is more serious for novice teachers who have no first-hand experience with ESP pedagogy and struggle to find the path in such a "thorny way of professionalization" [14]. Authors such as Labassi [15], Ghanbari and Rasekh [14] identify the lack of independent disciplinary status of ESP as a cause of excessive workload for ESP teachers. Despite its increasingly recognized importance in Vietnam, ESP has been treated merely as a composition of English language curriculum; hence, ESP teachers are also in charge of other General English courses (in case of EFL teachers teaching ESP) and subject courses (in case of subject teachers teaching ESP) which require time and effort to conduct. Teaching ESP requires more time and effort than other English language courses not because of its nature but because Vietnamese ESP teachers taking over their teaching task without being equipped with theoretical and practical knowledge about the domain as ESP education has yet been introduced in English teacher training program in the country.

For the nature and objectives of ESP pedagogy, it has been proved that language teachers are more suitable for ESP teaching than teachers of subject knowledge [13]; however, the insufficiency of specialist knowledge is the most prominent issue facing ESP teachers. The majority of ESP teachers are bewildered by the specialist content that they have to teach in ESP materials and with which they are not familiar. As a consequence, these teachers face "subject knowledge dilemma" [11] during their practice. An empirical research conducted by $\mathrm{Wu}$ and Badger studies typical classroom situations in which teachers are challenged by their lack of expertise, and the strategies employed to overcome such situations. The research, however, shows that not all of these strategies are successful, and they are merely ad hoc which fail to solve the problem thoroughly. Even in some cases, the teachers take risk ignoring the accuracy of their answers to "keep face". The problem also arises outside the classroom as ESP teachers are in charge of material design and development for the courses [11]. Apparently, this lack of content understanding may lead to incomprehensive teaching materials. Zhang proposes collaborative teaching with both teachers of EFL and content knowledge as ESP instructors teaching one class together [12]. However, this approach works best in institutions where there are both content and language teachers. Given ESP courses are now also offered for English majors in language institutions, this method is not feasible. Also, no mechanism has been developed to enable and monitor such collaboration in Vietnam. For the time to come, the application of this approach remains unachievable.

\section{B. Student-Related Problems}

Authors such as Hayati [9], Mazdayasna and Tahririan [10], Nguyen [1], Robinson [7], and Zhang [12] argue that challenges in ESP practices also come from learners. This paper identifies students' low English proficiency, lack of motivation and inappropriate learning style as the major student-related problems in ESP practice in Vietnam.

First, despite the fact that English has been a compulsory subject in Vietnam secondary schools and introduced to elementary schools from grade 2, Vietnamese students have failed to achieve high rank concerning their English proficiency. The situation gets worse given there is an unequal access in language education between rural and urban areas in Vietnam. The root of this problem can be traced back to the traditional teacher-centered approach which is prevalent in foreign language teaching in secondary level in 
Vietnam. With this emphasis on grammar and non-communicative skills, i.e. writing and reading, high school graduates encounter considerable problems listening to and speaking English as they use the language in colleges and universities. Furthermore, although students are required to complete general English language units and attained immediate level before starting ESP courses, these units fail to provide learners with a solid foundation given a short period of one or two semesters [1]-[12].

Another eminent issue coming from the students, which is not only peculiar to the case of Vietnam, is the lack of motivation. Hayati [9], Nguyen [1] and Mazdayasna and Tahririan [10] blame this problem for the fact that students are more examination driven than needs driven. This is rational considering an examination-oriented teaching method focusing on vocabulary and grammar as mentioned above. Although learners' need to be satisfies by ESP is the main factor motivating students [3], the current approach fails to meet students' needs of being able to use the language for communication purposes as most of the time in the classroom is spent on introducing terminology and translation. Another cause is the considerable size of language class in Vietnam with up to 60 students or more [1]. In such a big classroom, it is not easy for the teacher to manage the class and involve all students. Apparently, traditional approach cannot help enhance learners' engagement in classroom activities.

As an unavoidable result of the teacher-centered, didactic approach which is popular in secondary education, students have to struggle against their dependent and inactive learning methods to adapt to the more demanding and independent environment in tertiary level [1]. Students' passive learning style compromises with the aforementioned inappropriate ESP approach implemented by teachers making the situation worse. The study conducted by Utsumi \& Doan finds that there has witnessed a shift from little or no communicative toward highly communicative approach in language teaching in Vietnam [16]. Since the teaching/learning of ESP is not excluded in this trend, students' inherent passive learning is apparently a hurdle to this change.

\section{Other Issues}

Other issues coping both ESP learners and practitioners in Vietnam are the lack of resources and inadequately distributed time. First, regarding the problem of resources, Utsumi and Doan name the lack of material, library resources and insufficient professional development opportunities for ESP teachers as the major challenges to be addressed [16]. As there is no standard course books verified by the Vietnam Ministry of Education and Training, universities are allowed to decide on the materials used in their institutions. In this case, there are two possible solutions: imported commercial course books to be adopted or ESP teachers to compose their teaching materials. Either the former or latter case, ESP teachers who are struggling with their own specialist knowledge deficit, have to involve in the process. This task becomes more challenging given a lack of funding on library resources. Also, Labassi [15] agrees with Utsumi and Doan [16] upon considering poor professional development opportunities for ESP teachers as a barrier for ESP practitioners. This, in its turn, is a consequence of the non-disciplinary status of ESP. Finally, there is the question of time that needs to be addressed. The average duration for an ESP unit in Vietnamese universities is 15 weeks of up to nine class periods each week. Vietnamese students have to complete two or three ESP units before graduation. This amount of time is not sufficient given the amount of content knowledge to be introduced and language skills to be practiced.

In brief, the practice of ESP in Vietnam is coping with a wide variety of issues ranging from teachers, students to resources and time distribution. As ESP has been an inevitable tendency in EFL teaching/ learning, there is an urge to address these problems.

\section{Project-BASEd LEARNING: A CONDUCIVE APPROACH}

In the shift towards more communicative teaching, approaches under the umbrella of communicative language teaching (CLT) are increasingly employed. Among them, CBI has emerged as an effective method [1]. One advantage of CBI that makes it a popular approach in ESP practice is to engage students in the learning process as it allows them to learn content rather than the language per se. This paper proposes the application of PBL in ESP teaching not merely for it shares some similarities with CBI, but more importantly, it can address the aforementioned problems.

Firstly, concerning the question of "what to teach - content or language knowledge", it is clear that this problem cannot be solved merely by any pedagogical approach. The answer does not lie in PBL or other methods; it lies in teachers' perception of ESP and its goals, which is more of the responsibility of teacher training programs. However, PBL does help instructors feel more confident dealing with the problem as it enables the practice of language skills through content learning, which will be analyzed hereafter.

Teachers' workload on material design and development can be reduced in PBL classes because students are encouraged to find resources for their projects. That the students are in charge of finding input resources for their project does not mean the teacher plays no role in material and resource provision. The teacher is expected to be able to provide students with relevant resources and feedback to help them complete their work [17]. This practice, however, helps lessen the work on material design, especially for novice ESP teachers and the teachers who are not confident in their specialist subject knowledge. Markham, Mergendoller, Larmer and Ravitz argue that PBL requires more effort on assessment and evaluation [18]. Unlike traditional teaching, PBL should involve both formative and summative assessment, which is done not only by the teacher but the learners as well [19]. However, Markham, Mergendoller, Larmer and Ravitz admit that the creation of such assessment medium as rubrics can be shared between teachers and students [18]. Involvement in making rubrics and other assessment tools then can trigger students' motivation as students develop a sense of ownership of their own learning.

As PBL allows students to decide on and conduct their own project, the role of the teacher is no longer a knowledge provider but a facilitator helping students construct their 
knowledge [17]. The task of teachers is to guide, direct and assess students' learning process and outcome (Dewey as in [17]). Bell suggests teachers to confer with students on a regular basis to ensure they are on the right track and to offer scaffolding instruction to help students with their knowledge and skill gap [6]. Lee argues that one important task of the teachers in PBL classroom is to provide language support [20]. Levis and Levis conducted an empirical research in which learners of an EFL writing course carry out research project as a vehicle to learn professional writing in science and engineering contexts. The outcome reveals that PBL allows teachers to "address writing issues through authentic tasks without the barrier of field-specific content" [21]. However, to let students do their own researches and find information does not mean the teachers have no responsibility to learn about the content matter. In fact, teachers are expected to be knowledgeable masters [22]. Teachers should learn about the topics chosen by students to offer scaffolding advice if necessary [6]. This approach creates less in-class subject dilemma situations and provides chances for teachers to learn the content knowledge as well.

Regarding the issues of student low language proficiency, opponents of PBL might argue that PBL requires students' good command of English [23]. This is not necessarily true as Bell states that PBL "allows students to soar and learn at their own levels." [6]. She further explains that upon gleaning information, students choose resources compatible to their language level and technical understanding. Also, students will often challenge themselves by reaching higher, choosing materials that require higher level of proficiency. This will help them learn the language just as the materials used in traditional language classroom do because as a general rule, "materials should be slightly higher in their level of difficulty than the students' current level of English proficiency" (Kitao \& Kitao as in [24]). In fact, PBL is an effective approach that helps learners improve their language skills. PBL provides opportunities to practice the four language skills for a wide range of purposes, such as planning (speaking and listening), data collection (reading, speaking, listening) and communication of the product (writing, speaking) [25]. Hark back the study conducted by Levis \& Levis [21], the authors report an obvious improvement in learners' writing skill and their awareness of this enhancement as well as the willingness to work harder on their writings. Also, a study of the implementation of project work in English language classroom was conducted in Greece prefecture of Achaia. Fifteen sixth graders and two primary school teachers participated in a six-month project with the topic of local history. Students were asked to present a wide range of final products including a topographic map, an album with photographs and comments, a brochure advocating local ecosystem protection, and a PowerPoint presentation. The results showed considerable improvement in students' four language skills, especially speaking and listening ones. This improvement was attributable to the opportunities to use English in real and authentic communicative activities [8]. Given Vietnamese students are weak in communicative skills, PBL can be an optimum approach.

Beckett \& Slatter [26]; Beckett [27]; Gou [17]; Kobayashi [25] confirm the effectiveness of PBL in integrated language and content teaching. One notable feature of PBL is that it enables learners to develop better understanding of the topic [6]. This deeper understanding is achieved through learners' processes of problem solving, making knowledge connection and applying the knowledge to different contexts. PBL also allows student to "learned new concepts faster, retained them longer and were able to use them in class discussions" [2]. That the benefit of PBL in language classroom is twofold makes this approach appropriate for ESP pedagogy which aims at achieving language improvement in specific contexts. An empirical research on the effectiveness of PBL in ESP was undertaken in a business English classroom of forty MBA students. The class was divided into experimental group and control group. Students in experimental group were assigned four mini and one major term projects while the control group was taught in traditional approach with theoretical lessons. After the semester, both groups were tested for their communication skills. The statistics demonstrate that students of experimental group achieved more significant improvement. Besides, other language non-targeted skills such as reading and writing were ameliorated [28].

Another salient characteristic of PBL that helps solve student-related problems in ESP practice in Vietnam is its motivating nature. Firstly, since teachers do not seize control in PBL classroom and let students decide on their project work, this self-determination enhances motivation by developing a sense of ownership of their learning [29]. In addition, as students take an active part in evaluating their projects and those of their fellow students, this can evoke a sense of empowerment. Finally, students find more inspiration learning as they are engaged in real world tasks [6]. A study by Foss, Carney, MacDonald and Rooks involved 65 Japanese technical students participating in an intensive seven day English course. By conducting four projects of creating a Wikipedia entry, a newsletter and two videos, the participants were granted numerous chances to practice their four language skills with both native speakers (the teachers) and other students [29]. The short period of time did not reveal much significant linguistic improvement but evidenced there was students' high degree of motivation and chances of practice the language in authentic situations.

That PBL empowers students to learn autonomously avails them to change their passive learning style. PBL provides chances to obtain skills needed for active learning such as problem solving, self-reliant, being accountable, critical thinking, collaborative learning, and so forth [2], [6], [7], [26], [30]. It would be a challenge for students to embark upon independent learning given passive learning style is tolerated in lower levels of education. However, it is the role of the teacher as scaffolding instruction provider that can alleviate such challenge. As students are more mature or getting familiar with PBL, scaffold or support can be removed and students become self-directed and capable learners [6].

The findings of Beckett's study of 73 secondary school ESL students demonstrate a mixed attitude of learners towards PBL. Less than one fifth of the participants gave positive feedback about project work; one quarter had mixed feelings and the rest were not in favor of PBL [26]. This dissatisfaction reflects "potentially different philosophical, cultural, and linguistic beliefs held by students and teachers" 
(Beckett as in [26]). Similarly, Gou finds negative attitude towards PBL in both learners and teachers in China. She further reports the potential cause of this discontent as learners and teachers' reluctance with the transition from teacher- controlled to leaner-centered approach [17]. Considering the fact that, like China, Vietnam is a country under the influence of Confucianism ideology, the application of PBL into EFL and ESP might be hampered by this reluctance. It is true that secondary education in Vietnam still places the teacher in the center of the language classroom; however, there has witnessed attempts to introduce and apply more communicative approaches in language learning in tertiary level [16], [31], [32]. In addition, the use of Project Framework consisting of a planning graphic and a project diary can help address this problem by showing students' their language, content and skill development gained through the project [17], [26].

Other hurdles to the implementation of PBL in ESP can be name as limited resources, time consuming, PBL's feature of unpredictability which can be partly overcome by learners and teachers' creativity and engagement [17], [29]. Admittedly, removing such barrier as lack of resources requires the efforts of other forces than the single effort of teachers or learners. Therefore, this paper proposes PBL to be integrated as a composition of current ESP courses together with other approaches.

\section{CONCLUSION}

This paper is an attempt to delineate the picture of current ESP practice in Vietnam's higher institution. As ESP is an unavoidable trend in ELT and now becomes an important composition in tertiary education foreign language program in Vietnam, it is crucial to address problems arising upon the implementation of ESP courses. Taking into account the benefits it can bring to ESP classroom, PBL is a viable and conducive pedagogical approach that should be applied to surmount major obstacles facing both ESP learners and practitioners. However, it should be noted that PBL is ideal for solving ESP teaching problems at classroom level, issues such as the dearth of teaching/learning resources, poor professional development opportunities for teachers cannot be solved solely by PBL or any other approach. Nor can these problems be addressed by single effort of the teachers or students. Attempts at institutional level should be involved to remove such barriers. Furthermore, as communicative, learner-centered approach is probing its way into EFL (English as a Foreign Language) teaching/ learning in Vietnam, PBL and other communicative approach are inevitably being employed; however, it (PBL) cannot completely replace other approaches in ELT and ESP given the cultural and philosophical beliefs that the country's education is grounded on.

\section{REFERENCES}

[1] N. Nguyen, "Content-based instruction in the teaching of English for accounting at Vietnamese college of finance and customs," English Language Teaching, vol. 4, no. 3, pp. 90-100, 2011.

[2] G. Beckett, "Teacher and student evaluations of project-based instruction," TESL Canada Journal, vol. 19, no. 2, pp. 52-66, 2002.
[3] T. Hutchinson and A. Waters, English for Specific Purposes: A Learning-Centered Approach, Cambridge: Cambridge University Press, 1987, p. 19.

[4] A. Ibrahim, "ESP at tertiary level: Current situation, application and expectation," English Language Teaching, vol. 3, no. 1, pp. 200-204, 2010.

[5] G. Kavaliauskiene, "Research into the integration of content-based instruction into the ESP classroom," Journal of Language and Learning, vol. 2, no. 1, pp. 14-23, 2004.

[6] S. Bell, "Project-based learning for the $21^{\text {st }}$ century: Skills for the future," Clearing House: A Journal of Educational Strategies, Issues and Ideas, vol. 83, no. 2, pp. 39-43, 2010.

[7] J. K Robinson, "Project-based learning: Improving student engagement and performance in the laboratory," Analytical and Bioanalytical Chemistry, vol. 405, no. 1, pp. 7-13, 2013.

[8] I. Tsiplakides and I. Fragoulis, "Project-based learning in the teaching of English as a foreign language in Greek primary schools: From theory to practice," English Language Teaching, vol. 2, no. 3, pp. 113-119, 2009.

[9] A. Hayati, "Teaching English for special purposes in Iran: Problems and suggestions," Arts and Humanities in Higher Education: An International Journal of Theory, Research and Practice, vol. 7, no. 2, pp. 149-164, 2008.

[10] G. Mazdayasna and M. Tahririan, "Developing a profile of the ESP needs of Iranian students: The case of students of nursing and midwifery," Journal of English for Academic Purposes, vol. 7, no. 4, pp. 277-289, 2008.

[11] H. Wu and R. Badger, "In a strange and uncharted land: ESP teachers' strategies for dealing with unpredicted problems in subject knowledge during class," English for Specific Purposes, vol. 28, no. 1, pp. 19-32, 2009.

[12] J. Zhang, "Collaborative instructors and mixed learners: An English for specific purposes teaching model in China," Canadian Social Science, vol. 7, no. 5, pp. 144-150, 2011.

[13] O. Tabatabaei, "Who qualifies to monitor an ESP course: A content teacher or a language teacher?" Indian Journal of Applied Linguistics, vol. 33, no. 1, pp. 77-85, 2007

[14] B. Ghanbari and A. Rasekh, "ESP practitioner professionalization through apprenticeship of practice: The case of two Iranian ESP practitioners," English Language Teaching, vol. 5, no. 2, pp. 112-122, 2012.

[15] T. Labassi, "Two ESP projects under the test of time: The case of Brazil and Tunisia," English for Specific Purposes, vol. 29, no. 1, pp. 19-29, 2010.

[16] L. Utsumi and H. Doan, "Trends in teaching and learning English in Vietnam: Implications for the future," presented at the VTTP Workshop, CHEER for Viet Nam - Traversing Borders: Viet Nam Teacher Program, 2010.

[17] Y. Gou, "Project-based English as a foreign language education in China," in Project-Based Second and Foreign Language Education: Past, Present, and Future, G. H. Beckett and P. C. Miller, Eds. USA Information Age Publishing, 2006, pp. 143-158.

[18] T. Markham, J. Mergendoller, J. Larmer, and J. Ravitz, Project Based Learning Handbook, Canada: Buck Institute for Education, 2003.

[19] T. Slater, G. Beckett, and C. Aufderhaar, "Assessing projects as second language and content learning," in Project-Based Second and Foreign Language Education: Past, Present, and Future, G. H. Beckett and P C. Miller, Eds. USA: Information Age Publishing, 2006, pp. 241-261

[20] I. Lee, "A touch of class," Canadian Modern Language Review, vol. 59, no. 2, pp. 282-290, 2002

[21] J. Levis and G. Levis, "A project-based approach to teaching research writing to nonnative writers," IEEE Transactions on Professional Communication, vol. 46, no. 3, pp. 210-220, 2003.

[22] P. C. Blumenfeld, E. Soloway, R. W. Max, J. Krajcik, M. Guzdial, and A. Palincsar, "Motivating project-based learning: Sustaining the doing, supporting the learning," Educational Psychologist, vol. 26, no. 3-4, pp. 369-398, 1991

[23] M. Gibbes and L. Carson, "Project-based language learning: an activity theory analysis," Innovation in Language Learning and Teaching, vol. 8, no. 2, pp. 171-189, 2014.

[24] S. Diniah, "The teachers' perceptions towards the use of English textbook in EFL classrooms (A descriptive study of EFL teachers at one Islamic senior high school in Cirebon)," Journal of English and Education, vol. 1, no. 2, pp. 72-81, 2013

[25] M. Kobayashi, "Second language socialization through an oral project presentation: Japanese university student's experience," in Project-Based Second and Foreign Language Education: Past, 
Present, and Future, G. H. Beckett and P. C. Miller, Eds. USA: Information Age Publishing, 2006, pp. 71-94.

[26] G. Beckett and T. Slatter, "The project framework: A tool for language, content, and skill integration," ELT Journal, vol. 59, no. 2, pp. $108-116,2005$

[27] G. Beckett, "Beyond second language acquisition: Secondary school EFL teacher goals and actions for project-based instruction," in Project-Based Second and Foreign Language Education: Past, Present, and Future, G. H. Beckett and P. C. Miller, Eds. USA Information Age Publishing, 2006, pp. 55-70.

[28] F. Janjua, "Project based learning in business English classroom," Language in India, vol. 13, no. 1, pp. 38-47, 2013.

[29] P. Foss, N. Carney, K. MacDonald, and M. Rooks, "Project-based learning activities for short-term intensive English programs," Asian EFL Journal, vol. 23, pp. 1-19, 2007.
[30] D. Matejka, "Project-based learning in online postgraduate education," Issues in Informing Science \& Information Technology, vol. 1, pp 489-496, 2004.

[31] H. Pham, "University English classroom in Vietnam," ELT Journal, vol. 59, no. 4, pp. 336-338, 2005.

[32] S. Lam, R. Cheng, and H. Choy, "School support and teacher motivation to implement project-based learning," Learning and Instruction, vol. 20, no. 6, pp. 487-497, 2010.

Nguyen Van Khanh was born in Hanoi, Vietnam, on June 13, 1987. She has been doing the course master in TESOL at Monash University, Melbourne, Victoria, Australia since 2014.

She is currently a lecturer at the Faculty of Foreign Languages, Hanoi University of Science and Technology. Her research interests includes English for specific (ESP) pedagogy, world Englishes, and teaching methodologies. 